\title{
Retraction Note To: Artificial neural network to predict the effect of heat treatments on Vickers microhardness of low-carbon $\mathrm{Nb}$ microalloyed steels
}

\author{
Gholamreza Khalaj $^{1} \cdot$ Hossein Yoozbashizadeh $^{1} \cdot$ Alireza Khodabandeh $^{1} \cdot$ Ali Nazari $^{1}$
}

Published online: 11 January 2021

(C) Springer-Verlag London Ltd., part of Springer Nature 2021

\section{Retraction Note To: Neural Comput \& Applic (2013) 22:879-888 https://doi.org/10.1007/s00521-011-0779-z}

The Editor-in-Chief has retracted this article [1] because it significantly overlaps with number of articles including those that were under consideration at the same time [2] and previously published articles [3-6]. Additionally, the article shows evidence of peer review manipulation.

Gholamrezah Khalaj disagrees with this retraction. Alireza Khodabandeh agrees with this retraction but not to the wording of this retraction notice. Hossein Yoozbashizadeh and Ali Nazari have not responded to correspondence regarding this retraction.

\section{References}

[1] Khalaj G, Yoozbashizadeh H, Khodabandeh A et al (2013) Artificial neural network to predict the effect of heat treatments on Vickers microhardness of low-carbon $\mathrm{Nb}$ microalloyed steels.
Neural Comput Appl 22:879-888. https://doi.org/10.1007/ s00521-011-0779-z

[2] Khalaj G, Yoozbashizadeh H, Khodabandeh A et al (2013) Modeling hardness of Nb-microalloyed steels using fuzzy logic. Neural Comput Appl 23:207-214. https://doi.org/10.1007/ s00521-011-0802-4

[3] Dehghani K, Nekahi A (2010) Artificial neural network to predict the effect of thermomechanical treatments on bake hardenability of low carbon steels. Mater Des 31(4):2224-2229. https://doi.org/ 10.1016/j.matdes.2009.10.020

[4] Çöl M, Ertunç HM, Yılmaz M (2007) An artificial neural network model for toughness properties in microalloyed steel in consideration of industrial production conditions. Mater Des 28(2):488-495. https://doi.org/10.1016/j.matdes.2005.09.001

[5] Yilmaz M, Metin Ertunc H (2007) The prediction of mechanical behavior for steel wires and cord materials using neural networks. Mater Des 28(2):599-608. https://doi.org/10.1016/j.matdes.2005. 07.016

[6] Tafteh R (2011) Austenite decomposition in an X80 linepipe steel (T). Electronic theses and dissertations (ETDs) 2008+. University of British Columbia. Retrieved 22 Sept 2020, from https://open. library.ubc.ca/collections/ubctheses/24/items/1.0078491

Publisher's Note Springer Nature remains neutral with regard to jurisdictional claims in published maps and institutional affiliations.

The original article can be found online at https:// doi.org/10.1007/s00521-011-0779-z.

\section{Gholamreza Khalaj}

gh.khalaj@srbiau.ac.ir

1 Department of Materials Engineering, Science and Research Branch, Islamic Azad University, Tehran, Iran 